JIIP: Jurnal IImiah IImu Pemerintahan

Volume 5, Nomor 1, Tahun 2020

DOI: 10.14710/jiip.v5i1.7311

\title{
Selebritis Menjadi Politisi: Studi tentang Bagaimana Selebritis Menang atau Kalah dalam Pemilu Legislatif
}

\author{
HB Habibi Subandi ${ }^{1}$, Ahmad Hasan Ubaid ${ }^{2}$ \\ 1,2 Program Studi Ilmu Politik, Universitas Brawijaya
}

\begin{abstract}
Intisari
Artikel ini menyorot model pemasaran politik dengan memanfaatkan kandidat caleg selebritis pada Pemilu 2019. Untuk itu studi ini berupaya menjawab fenomena maraknya pencalonan selebritis sebagai caleg DPR RI, yang dikaitkan dengan sistem pemilu yang berorientasi pada figur. Kajian ini menggunakan metode kualitatif dengan pendekatan studi kasus, khususnya dengan melacak bagaimana performa politisi selebritis selama kampanye. Adapun data yang dipakai adalah data survey Laboratorium Politik dan Rekayasa Kebijakan (Lapora) di Dapil Jawa Timur I, V, dan VIII. Hasil riset menyimpulkan bahwa seiring munculnya metode penghitungan suara saint lague, tingkat keterpilihan politisi selebritis semakin lemah dalam kontestasi antar calon legislatif dan antar partai. Mesin partai dan popularitas partai justru menjadi supporting system yang menentukan keterpilihan seorang calon anggota legislatif. Selebritis yang akhirnya terpilih, tidak terlepas dari keberhasilan mereka dalam mengkonsolidasikan tim pemenangan partai, merancang program-program pemasaran politik yang langsung menyasar pemilih, dan pencitraan politik yang menggunakan episentrum masyarakat sebagai komunikasi parasosial.
\end{abstract}

\section{Kata Kunci}

pemasaran politik; mobilisasi suara; politisi selebritis; popularitas; komunikasi parasosial

\section{Pendahuluan}

S elama satu dasawarsa terakhir, partai politik di Indonesia semakin memberi ruang bagi para selebriti untuk terlibat aktif dalam kontestasi pemilihan legislatif maupun pemilihan kepala daerah. Pelibatan selebritis memiliki motif elektoral untuk meningkatkan variabel popularitas dan elektabilitas partai politik pada masa kampanye dan pemilihan umum. Kedua variabel tersebut menjadi isu yang selalu mengemuka dalam setiap gelaran pemilihan umum maupun pemilihan kepala daerah, dan cenderung menggerus aspek visi kepemimpinan, arah kebijakan, dan manifesto ideologi dari kandidat maupun calon (Lane, 2015).

Studi tentang keterlibatan selebritis kian menarik dikaji karena ada kecenderungan peningkatan jumlah selebritis yang turut serta menjadi vote getter 
HB Habibi S. \& Ahmad H. Ubaid | Selebritis Menjadi Politisi: Studi tentang Bagaimana Selebritis Menang...

partai dalam Pemilu Legislatif. Penelitian sebelumnya mencatat bahwa terjadi peningkatan jumlah caleg selebritis dari Pemilu 2004 (38 orang), Pemilu 2009 (61 orang) dan Pemilu 2019 (77 orang) (Darmawan, 2015). Pada gelaran Pemilu 2019, sebanyak 91 kandidat selebritis kembali tercatat namanya pada kertas suara calon anggota DPR RI (Kumparan, 2018). Bagi partai politik, kepentingan yang ingin dalam kandidasi selebritis adalah menambah perolehan suara dan mencapai batas minimum parliamentary threshold sebesar $4 \%$. Sementara bagi para selebritis, kesuksesan dan kegagalan mereka untuk lolos ke Senayan akan sangat bergantung dari upaya mereka selama kampanye. Alhasil, pada Pemilu 2019 ini hanya tercatat sejumlah 14 politisi selebritis yang lolos menjadi anggota DPR. Ini menjadi indikasi bahwa strategi partai politik mengusung caleg artis ternyata tidak selalu berhasil.

Studi ini berupaya melihat kembali kebijakan kandidasi politisi selebritis dengan menyajikan data terbaru dari Pemilihan Umum 2019. Caleg selebritis yang selama ini sering menjadi sorotan media massa meliputi para aktor dan aktris dari industri perfilman, pemain sinetron, penyanyi, hingga model. Jumlah caleg selebritis itu masih bisa bertambah jika definisi tentang politisi selebritis diperluas dengan tidak hanya merujuk pada mereka yang berasal dari industri hiburan. West dan Orman mengidentifikasi 4 jenis politisi selebritis diantaranya mereka yang punya skill public relations dan promosi diri; para selebritis yang mendapat popularitas berkat warisan dari orang tua atau pasangan suami/istri mantan politisi; selebritis dadakan yang disorot media karena suatu kejadian penting; dan figur terkenal non-politisi yang berasal dari industri hiburan (West \& Orman, 2003).

Studi-studi sebelumnya tentang politisi selebritis di Indonesia memiliki kelemahan dalam memperoleh data tentang strategi para selebritis di lapangan. Permasalahan yang dialami peneliti ialah bahwa pencalonan selebritis itu dilakukan pada daerah pemilihan yang berbeda-beda. Sehingga studi yang dilakukan tidak mampu menjawab faktor kunci yang membuat selebritis terpilih menjadi anggota DPR dan faktor yang menjadi kegagalan mereka. Studi terbaru tentang tema ini masih sebatas mengangkat perdebatan teoritik keterlibatan selebritis dalam Pemilu dengan menggunakan metode studi literatur dan data sekunder (Darmawan, 2015). Kesimpulan studi itu menyebut bahwa maraknya partai politik mencalonkan anggota DPR dari kalangan selebritis disebabkan perubahan sistem Pemilu yang menekankan pada pemasaran figur dan meningkatnya pragmatisme partai politik dalam Pemilu 2009 dan 2014. Artikel serupa dengan metode serupa juga diangkat oleh Wasisto Raharjo Jati yang mengungkap politik selebritis sebagai model kampanye baru dalam perpolitikan di Indonesia (Jati, 2014).

Literatur review yang tersedia mengenai politik selebritis ini memang masih didominasi oleh penelitian di negara demokrasi maju. Sebagai contoh penelitian yang dilakukan oleh Lara Zwarun dan Angela Torrey (2011) tentang politisi selebritis Hollywood dalam kontestasi Pemilu di Amerika Serikat. Penelitian itu melihat bahwa selebritis dapat menjadi isyarat heuristik atau simbol pengenal yang mudah bagi pemilih. 
Selebritis merupakan figur yang memiliki popularitas tinggi dan dapat menarik perhatian masyarakat untuk mencurahkan atensi mereka pada proses politik (Zwarun \& Torrey, 2011). Secara umum pelibatan selebritis dalam politik di Amerika Serikat, baik sebagai kandidat atau endorser, dimaksudkan untuk menarik perhatian pemilih yang mayoritas acuh tak acuh pada penyelengaraan Pemilu. Studi dari Natalie Wood mencatat bahwa endorsement selebritis dalam kampanye dapat menjadi faktor hipness bagi kandidat yang dianggap terlalu konservatif atau ketinggalan zaman (Wood \& Herbst, 2007).

Bagi penulis, studi tentang politik selebritis di luar Indonesia itu tidak dapat menjadi acuan untuk melihat fenomena pencalonan selebritis di Indonesia. Fenomena meningkatnya calon selebritis di Indonesia ini menandai suatu perubahan strategi kandidasi di tubuh partai politik dan model pemenangan Pemilu. Pencalonan selebritis biasanya didasarkan oleh beberapa pertimbangan mendasar. Pertama, selebritis tersebut memiliki hubungan kedaerahan dengan daerah pemilihan (Dapil) dimana mereka didaftarkan sebagai calon. Ini dimaksudkan agar selebritis membantu partai melakukan strategi positioning dan pencitraan yang tepat di dapil yang bersangkutan. Kedua, kandidasi selebritis di suatu dapil dimaksudkan untuk mempertahankan perolehan suara di suatu dapil agar tidak menurun. Ini dilakukan ketika tidak ada lagi calon petahana yang diusung dari dapil tersebut. Misalnya saja pencalonan Denada di Dapil Jawa Timur VIII dimaksudkan agar suara PAN tidak turun dengan hengkangnya Eko Patrio sebagai petahana dari Dapil yang bersangkutan.

Studi ini berupaya menjawab dua pertanyaan mendasar yang selama ini belum terjawab dalam artikel tentang politisi selebritis di Indonesia. Pertama, bagaimana strategi pemasaran politik selebritis selama masa kampanye Pemilu serentak 2019? Kedua, apa saja faktor penentu dan penghambat pemenangan kandidat selebritis dalam Pemilu? Hal ini dilakukan dengan memfokuskan pada data yang tersedia dari survey Laboratorium Politik dan Rekayasa Kebijakan (Lapora) di Dapil Jawa Timur I, Jawa Timur V, dan Jawa Timur VIII. Pada tiga daerah pemilihan tersebut terdapat 6 figur selebritis yang dinominasikan sebagai calon anggota DPR RI, diantaranya yaitu:

Tabel 1. Daftar caleg selebritis dan perolehan suaranya di Dapil Jatim I, V, dan VIII

\begin{tabular}{|c|c|c|c|c|}
\hline No & Nama Caleg Selebritis & Partai & Dapil & Keterangan \\
\hline 1 & Ahmad Dhani & Gerindra & $\begin{array}{c}\text { Jawa } \\
\text { Timur } \\
\text { I }\end{array}$ & $\begin{array}{l}\text { Caleg nomor urut } 2 \text {. Ahmad } \\
\text { Dhani tidak lolos menjadi } \\
\text { anggota DPR RI dengan } \\
\text { perolehan suara terbanyak } \\
\text { ketiga di internal partai ( } 40148 \\
\text { suara). Suara terbanyak } \\
\text { pertama diperoleh H. Rahmat } \\
\text { Muhajirin, SH (86274 suara) } \\
\text { dan kedua Ir. H. Bambang Haryo } \\
\text { Soekarto (52451 suara) }\end{array}$ \\
\hline
\end{tabular}


HB Habibi S. \& Ahmad H. Ubaid | Selebritis Menjadi Politisi: Studi tentang Bagaimana Selebritis Menang...

\begin{tabular}{|c|c|c|c|c|}
\hline 2 & Andre Hehanusa & PDIP & $\begin{array}{c}\text { Jawa } \\
\text { Timur } \\
\text { I }\end{array}$ & $\begin{array}{l}\text { Caleg nomor urut } 5 . \text { Andre } \\
\text { Hehanusa hanya memperoleh } \\
\text { suara sebanyak kelima dengan } \\
26139 \text { suara) }\end{array}$ \\
\hline 3 & Arzetti Bilbina, SE, MAP & PKB & $\begin{array}{c}\text { Jawa } \\
\text { Timur } \\
\text { I }\end{array}$ & $\begin{array}{l}\text { Caleg nomor urut 2. Arzetti } \\
\text { lolos ke Senayan dengan } \\
\text { memperoleh suara terbanyak } \\
\text { kedua di internal partai sebesar } \\
53185 \text { suara. }\end{array}$ \\
\hline 4 & Manohara Odhelia & Nasdem & $\begin{array}{c}\text { Jawa } \\
\text { Timur } \\
\text { I }\end{array}$ & $\begin{array}{l}\text { Caleg nomor urut } 6 \text {. Tidak lolos } \\
\text { menjadi anggota DPR RI dan } \\
\text { hanya memperoleh suara } \\
\text { sebesar } 6865 \text {, terbanyak kelima } \\
\text { di internal partai. }\end{array}$ \\
\hline 5 & Krisdayanti & PDIP & $\begin{array}{c}\text { Jawa } \\
\text { Timur } \\
\text { V }\end{array}$ & $\begin{array}{l}\text { Caleg nomor urut } 2 \text {. Krisdayanti } \\
\text { berhasil lolos menjadi anggota } \\
\text { DPR RI dengan perolehan suara } \\
\text { terbanyak pertama di Dapil } \\
\text { Jatim V sebesar } 132131 \text { suara. }\end{array}$ \\
\hline 6 & Denada & PAN & $\begin{array}{l} \\
\text { Jawa } \\
\text { Timur } \\
\text { VIII }\end{array}$ & $\begin{array}{l}\text { Caleg nomor urut } 1 . \text { Denada } \\
\text { hanya menduduki posisi kedua } \\
\text { di internal partai dengan } \\
\text { perolehan suara sebesar } 43573 . \\
\text { Caleg PAN yang lolos menjadi } \\
\text { anggota DPR RI adalah Abdul } \\
\text { Hakim Bafagih yang } \\
\text { memperoleh suara sebesar } \\
56848 \text {. }\end{array}$ \\
\hline
\end{tabular}

Sumber: Data rekapitulasi penghitungan perolehan suara Model DC1 DPR (KPU RI, 2019a, 2019b, 2019c)

Penelitian ini menggunakan metode kualitatif dengan pendekatan studi kasus. Penelitian ini difokuskan pada case by case partai politik yan menggunakan figur selebritis sebagai vote getter dalam pemilihan legisatif. Ketiga dapil tersebut dipilih karena secara geografis berdekatan, dan dengan demikian, peneliti memiliki akses terhadap ketersediaan sumber data (Johnson, Reynolds, \& Mycoff, 2015). Peneliti menggunakan metode tracing atau pelacakan hasil survey untuk melihat bagaimana kontestasi antar caleg di masing-masing Dapil. Selain itu, untuk memperdalam analisis, peneliti juga mewawancarai Tim Sukses Caleg dan Tim Kampanye Partai politik bersangkutan yang memahami tentang proses pemilu dan pemenangan caleg selebritis. Di Dapil Jawa Timur I, peneliti berhasil mewawancara Hendro Tri Subiantoro sebagai tim 
pemenangan calon legislatif RI Partai Gerindra Dapil Jatim I, Achmad Faidy Suja'ie sebagai tim pemenangan Arzetti Bilbina, dan Valentinus Barobeda Casay sebagai Sekretaris DPW partai Nasdem. Peneliti berhasil mewawancara Juius Eduardo Foeh, sebagai coordinator tim pemenangan Krisdayanti di Dapil Jawa Timur V. Di Dapil VIII, peneliti mewawancara pengurus salah satu Pengurus DPD PAN Kabupaten Jombang.

\section{Model Pemasaran Politik Dalam Pemilu Legislatif}

Model pemasaran politik menyandarkan diri pada strategi dan cara partai politik menyampaikan produk politik kepada pemilih. Produk politik, bagi O'shaughnessy, dapat diartikan sebagai partai politik dan kandidat. Pada praktiknya, model pemasaran politik akan bergantung pada jenis produk politik yang akan disampaikan kepada pemilih. Pemasaran produk politik berupa partai dengan ideologinya akan memiliki cara dan strategi yang berbeda dengan pemasaran produk berupa figur atau kandidat. Dalam Pemilihan Kepala Daerah, misalnya, produk politik yang akan disampaikan kepada pemilih adalah berupa ketokohan seorang kandidat dan visi-misi serta program yang dimilikinya. Sementara dalam Pemilu legislatif seorang kandidat atau manajer kampanye akan berupaya membuat sinkronisasi antara ideologi dan platform partai, pencitraan dan kapabilitas individu, serta program-program kampanye di lapangan.

Model pertama yang dikenal dalam pemenangan pemilu legislatif di Indonesia adalah model brokerage. Model ini pelaksanaannya cukup sederhana dimana partai dan kandidat dalam pemilihan umum akan mengkonsolidasikan tim sukses internal yang berfungsi sebagai mesin pendulang suara dalam pemilihan umum. Tim sukses ini terdiri dari tokoh-tokoh simpul masyarakat atau terma lainnya adalah broker suara. Berdasarkan terminologi yang dikemukakan Robin Lent dan Genevieve Tour, tokoh simpul masyarakat ini ibaratnya merupakan duta-duta pemasaran, sales ambassador, untuk menyampaikan berbagai hal terkait produk politik yang dipasarkan (Lent \& Tour, 2009). Penetrasi politik untuk menggalang dukungan dan suara dilakukan secara hirarkis dan transaksional. Dalam pengalaman-pengalaman Pemilu di Indonesia, pelaksanaan model brokerage menjadi ciri utama dalam Pemilihan Umum tahun 2004, tahun 1999 dan pemilihan umum di era Orde Baru. Hal ini terjadi akibat sistem pemilu yang dilaksanakan pada saat itu yang lebih memprioritaskan pada sistem pemilu Partai.

Model brokerage ini kemudian secara perlahan bergeser sejak pemilihan umum tahun 2009, dimana sejak saat itu proses penghitungan suara dilakukan berdasarkan sistem proporsional terbuka dengan metode penghitungan suara terbanyak. Persaingan antar calon legislatif lebih terbuka dan memunculkan model baru dalam pemenangan pemilu. Kampanye yang dilaksanakan oleh figur calon legislatif lebih mengemuka daripada kampanye berdasarkan partai. Menurut Edward Aspinall, sistem pemilu proporsional terbuka ini memberikan kontribusi yang besar bagi para kandidat calon anggota legislatif untuk melakukan kampanye untuk diri mereka sendiri daripada untuk 
HB Habibi S. \& Ahmad H. Ubaid | Selebritis Menjadi Politisi: Studi tentang Bagaimana Selebritis Menang...

partai. Para kandidat dari partai politik yang sama kemudian berlomba satu sama lain untuk membangun tim kampanye personal yang memanfaatkan para tokoh masyarakat atau patron untuk melakukan persuasi dan mobilisasi pemilih(Aspinall, 2014). Akibatnya, para figur saling berkompetisi untuk mengenalkan keunggulan dirinya kepada masyarakat dan juga membentuk jaringan para broker suara yang secara tradisional merupakan bagian dari mesin partai.

Gambar 1: Struktur mobilisasi suara berdasarkan model pemasaran politik figur

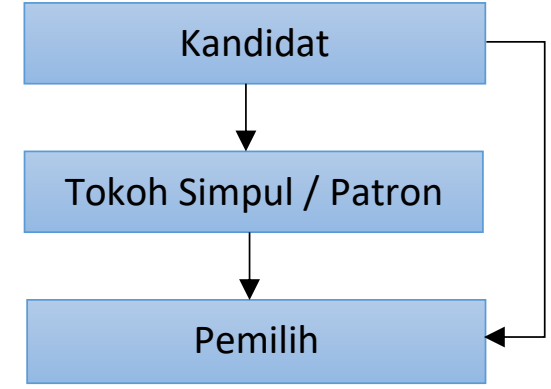

Sumber: disadur dari model patronage politics (Aspinall, 2014)

Struktur model pemasaran politik ini mensyaratkan seorang kandidat harus turun langsung kepada masyarakat dengan program seperti canvassing dan door to door campaign. Memang posisi tokoh simpul masyarakat sebagai duta bagi kandidat dalam politik tidak hilang secara an sich, namun pola pengorganisasian mereka lebih terafiliasi pada figur daripada partai. Pencitraan politik menjadi sangat penting untuk dilakukan agar produk politik semakin kuat dan diterima oleh masyarakat.

Pentingnya pencitraan politik ini kemudian melahirkan model pemasaran politik yang disebut sebagai model political branding. Menurut Scammell, Branding adalah bentuk baru dari political marketing dimana konsep brand dapat menjadi jaminan, keunikan (unsur pembeda yang jelas dengan rival), konsistensi nilai, dan hubungan emosional dengan nilai dan visi tentang kehidupan yang baik dari pemilih (Scammell, 2015). Menurut Lorann Downer, secara operasional model political branding ini harus dipilah menjadi 2 bagian yaitu konsepsi political branding yang ditujukan untuk merujuk pada institusi politik atau partai dan konsepsi political branding yang diatribusikan kepada figur (Downer, 2016).

Pada Pemilu tahun 2019, muncul suatu pola baru dalam political branding. Seiring dengan perkembangan kampanye lewat media sosial partai politik cenderung mengemas strategi political branding di tingkat nasional dan langsung mengkampanyekan kepada pemilih melalui media sosial. Kecenderungan ini terindikasi dari bagaimana strategi partai secara umum diantaranya melalui hastag \#2019GantiPresiden, hastag \#2019TetapJokowi, mendukung atau mengkritik kebijakan pemerintahan Jokowi, hingga mencalonkan figur selebritis.

Menguatnya model political branding yang mengarah pada pencitraan partai dan figur sekaligus semakin membuat partai politik juga mengusung kandidat selebritis sebagai alat untuk menarik perhatian pemilih saat kampanye. Kebijakan seperti ini 
dilakukan oleh beberapa partai yang mengusung banyak calon legislatif selebritis, khususnya Partai Nasdem (37 calon), PDIP (16 Calon), dan PAN (12 calon) (Kumparan, 2018). Strategi pencitraan partai melalui pencalonan selebritis ini dapat kita lihat secara khusus dilakukan oleh Partai Nasdem. Menurut Valentinus Barobeda Casay, sekretaris DPW Partai Nasdem Jawa Timur, disebutkan bahwa "ada kebijakan khusus dari DPP Partai Nasdem untuk caleg selebritis. Kebijakan itu berbentuk pemberian dana khusus untuk alat peraga kampanye dan biaya konsolidasi sedangkan untuk calon legislatif lain dari kalangan non-selebritis pemberian bantuan dana APK dan biaya konsolidasi ini tidak ada" (wawancara penulis, 1 Agustus 2019)

\section{Tantangan Caleg Selebritis dalam Model Sainte Lague}

Pemilu serentak 2019 telah berimplikasi pada munculnya mobilisasi suara secara sistematis yang terkait antara pemilihan Presiden, pemilihan anggota DPR RI, pemilihan anggota DPRD tingkat I, pemilihan anggota DPRD tingkat II, dan pemilihan anggota DPD. Pada praktiknya di saat-saat akhir menjelang terlaksanyanya Pemilihan serentak para tim sukses Partai dan tim sukses calon melakukan mobilisasi secara terstruktur. Hal ini utamanya dimotori oleh kinerja tim sukses nasional untuk pasangan Presiden dan Wakil Presiden. Pola mobilisasi suara secara serentak ini tentunya menguntungkan partaipartai dan calon-calon anggota legislatif yang terkoordinasi dengan calon PresidenWakil Presiden petahana, atau dalam hal ini yang tergabung dalam tim kampanye nasional Joko Widodo - Ma'ruf Amin.

Pada hampir semua Dapil di Jawa Timur, partai politik yang diuntungkan dengan adanya pelaksanaan Pemilu serentak tahun 2019 adalah PDIP dan PKB. Berdasarkan hasil akhir penghitungan suara Pemilu legislatif, kedua partai masing-masing menyumbangkan 20 dan 19 anggota DPR RI dari seluruh daerah Pemilihan di Jawa Timur. Khusus untuk Dapil I, V, dan VIII hasil survey pemilu legislatif yang menunjukkan preferensi pemilih terhadap partai politik juga berkesinambungan dengan perolehan suara untuk anggota DPR RI. Faktor penghitungan suara berdasarkan metode sainte lague, yang mengharuskan total suara perolehan suara partai dan kandidat untuk dibagi dengan bilangan pembagi ganjil (1, 3, 5, dan seterusnya), sangat mempengaruhi hasil akhir keterpilihan seorang kandidat. Sehingga, partai dengan komposisi calon legislatif yang bagus di kertas suara DPR RI, DPRD tingkat I, dan DPRD tingkat II dengan mudah bisa mengintegrasikan pola mobilisasi suara dengan tim sukses dari capres dan cawapres tertentu.

Metode sainte lague ini merubah hasil suara pada penetapan akhir hasil Pemilu. Pada Pemilu sebelumnya tahun 2014, KPU menetapkan bahwa metode penetapan sisa hasil suara Partai dilakukan di tingkat KPU Provinsi. Sementara dengan menggunakan metode sainte lague, tidak dikenal adanya penghitungan sisa suara yang diperoleh partai di Dapil. Suara akan dibagi habis pada masing-masing Dapil dengan bilangan 
HB Habibi S. \& Ahmad H. Ubaid | Selebritis Menjadi Politisi: Studi tentang Bagaimana Selebritis Menang...

pembagi ganjil $(1,3,5,7$, dst) yang telah ditetapkan. Hal ini membawa pengaruh signifikan bagi partai yang memiliki basis massa kuat di masing-masing Dapil. Pada Dapil I dan V, PDIP berhasil memperoleh 3 kursi. Hal ini mengindikasikan bahwa partai tersebut memiliki mesin partai dan basis kader yang sangat mengakar di wilayah Surabaya-Sidoardjo dan Malang Raya. Selain itu keberadaan Capres Joko Widodo menjadi daya tarik tersendiri bagi pencitraan PDIP selama kampanye. Sementara PKB secara umum hanya mampu meloloskan maksimal 2 orang calon pada Dapil I, V, dan VIII, yang disebabkan partai ini memiliki basis pemilih nahdliyin.

Dengan demikian data mengenai popularitas dan akseptabilitas para politisi selebritis yang dipaparkan sebelumnya tidak serta merta memberikan dampak pada tingkat keterpilihan mereka. Pada momen menjelang akhir masa kampanye dan sebelum hari pemilihan serentak digelar, terdapat upaya intervensi pemilih untuk mempengaruhi keputusan akhir pemilih menentukan pilihannya. Variabel voters intervention ini merujuk pada upaya mobilisasi suara melalui pendekatan berdasarkan banyaknya mobilisator pemilih yang dimiliki partai atau party wing, tim sukses seorang kandidat, kekuatan politik uang dari Partai maupun kandidat, pola intervensi melalui aparatur Pemerintah Daerah dan aparatur desa, hingga intervensi terhadap hasil Pemilu melalui saksi partai dan penyelenggara (Aminuddin \& Attamimi, 2019).

Pada gelaran pemilihan legislatif variabel intervensi pemilih melalui cara-cara mobilisasi secara sistemik ini memiliki signifikansi yang kuat bagi keterpilihan seorang kandidat. Para politisi selebritis memang memiliki keunggulan dalam hal popularitas yang memudahkan mereka untuk mengaplikasikan program kampanye yang menyasar pemilih. Namun pada saat akhir menjelang hari pemilihan para politisi selebritis masih tetap harus melakukan program intervensi pemilih ini, yang mayoritas dilakukan dengan cara politik uang.

Fakta perolehan suara pada Pemilihan Umum 2019 menjadi pelajaran tersendiri bagi para selebritis yang hendak mencalonkan diri sebagai calon legislatif. Mereka perlu mempertimbangkan kekuatan partai yang hendak mengusung mereka di masing-masing Dapil dimana mereka didaftarkan pada daftar Pemilih Tetap. Keputusan untuk maju dari suatu partai akan menentukan pada sejauh mana popularitas massa akan berpengaruh terhadap keterpilihan mereka nantinya. Ini disebabkan oleh fakta bahwa dengan menggunakan sistem pemilu saat ini, terdapat kecenderungan bahwa pada gelaran Pemilihan legislatif keterpilihan seorang kandidat tidak hanya ditentukan oleh strategi positioning dan pencitraan masing-masing figur calon legislatif. Tetapi kekuatan partai politik sebagai supporting system bagi calon juga menentukan keterpilihan seorang selebritis. Untuk menguatkan argumen ini, pembahasan pada sub bab berikutnya akan mengupas bagaimana relevansi hasil survey pilihan politik masyarakat berdasarkan partai politik berpengaruh terhadap keterpilihan seorang kandidat. 


\section{Popularitas sebagai Modal Utama Politisi Selebritis}

Para selebriti memiliki keunggulan pada aspek popularitas jika dibandingkan dengan calon-calon lain dengan latar belakang politisi, birokrat, pengusaha, dan bahkan agamawan. Keunggulan ini diperoleh dari banyaknya liputan media massa dan media sosial, dimana para selebriti mendapat panggungnya di dunia industri musik dan perfilman. Pada pelaksanaan Pemilu, variabel popularitas membantu kandidat selebritis pada saat memasuki masa kampanye. Dengan modal ketenaran ini para politisi selebritis mengawali kampanye dengan baik dan mengungguli calon-calon lainnya yang tidak terlalu dikenal masyarakat.

Secara umum pada berbagai event Pemilihan Legislatif atau Pemilihan Kepala Daerah, seorang calon yang terdaftar pada kertas suara akan mengejar tiga variabel penting; yaitu popularitas, akseptabilitas, dan elektabilitas (Ubaid \& Subandi, 2018). Variabel popularitas ini menjadi isyarat pengenal heuristik bagi pemilih. Pada variabel popularitas, seorang politisi selebritis bisa mengaplikasikan ketenarannya dengan lebih baik dibanding calon-calon legislatif lainnya. Sehingga seorang selebritis dapat berasumsi bahwa dia bisa langsung mengejar variable akseptabilitas atau penerimaan masyarakat terhadap pencalonannya sebagai politisi. Variabel akseptabilitas diukur dari tingkat kesukaan dan ketidaksukaan masyarakat terhadap kandidat calon. Untuk mencapai variabel ini, para calon perlu melaksanakan program-program kampanye intensif seperti kampanye blusukan, door to door dan canvassing. Ini untuk menunjukkan bahwa statusnya sebagai selebritis tidak menghalangi kepantasan mereka untuk terjun di dunia politik.

Tabel 2. Data Popularitas dan Akseptabilitas Calon Anggota DPR RI di Dapil Jatim I

\begin{tabular}{|c|c|c|c|c|c|c|}
\hline \multirow[b]{2}{*}{ No } & \multirow[b]{2}{*}{ Nama Calon Legislatif } & \multirow[b]{2}{*}{ Partai } & \multirow{2}{*}{$\begin{array}{c}\text { Popular- } \\
\text { Itas }\end{array}$} & \multicolumn{3}{|c|}{ Akseptabilitas } \\
\hline & & & & Suka & $\begin{array}{l}\text { Tidak } \\
\text { Suka }\end{array}$ & $\begin{array}{l}\text { Tidak } \\
\text { Jawab }\end{array}$ \\
\hline 1 & Ahmad Dhani Prasetyo & Gerindra & $21.0 \%$ & $23.60 \%$ & $19.6 \%$ & $56.8 \%$ \\
\hline 2 & Puti Guntur Soekarno, S.IP & PDI-P & $16.9 \%$ & $27 \%$ & $5 \%$ & $68 \%$ \\
\hline 3 & Arzetti Bilbina, S.E., M.AP & PKB & $16.0 \%$ & $18.3 \%$ & $2.7 \%$ & $79 \%$ \\
\hline 4 & Bambang DH & PDIP & $13.5 \%$ & $20 \%$ & $5 \%$ & $75 \%$ \\
\hline 5 & $\begin{array}{l}\text { H. Syaikhul Islam, LC, } \\
\text { M.Sosio }\end{array}$ & PKB & $6.4 \%$ & $10.8 \%$ & $1.1 \%$ & $88.2 \%$ \\
\hline
\end{tabular}

Sumber: Survey Lapora Periode Bulan Januari 2019 (Lapora, 2019a)

Pada prakteknya, variabel popularitas para selebriti tidak selalu dapat mengalahkan popularitas calon legislatif dari latar belakang lainnya, misalnya saja seorang calon petahana yang telah memiliki akar yang kuat di suatu daerah pemilihan. Berdasarkan hasil survey opini yang dilakukan oleh Lapora selama masa kampanye, figur Krisdayanti dan Ahmad Dhani berhasil mencatatkan angka popularitas tertinggi dari 
HB Habibi S. \& Ahmad H. Ubaid | Selebritis Menjadi Politisi: Studi tentang Bagaimana Selebritis Menang...

pemilih (lihat Tabel 2 dan 3). Sementara politisi selebritis lainnya yaitu Arzetti Bilbina dan Denada hanya menduduki peringkat ketiga pada variabel popularitas dan elektabilitas ini. Bahkan politisi selebritis lainnya seperti Manohara Odelia dan Andre Hehanusa masing-masing hanya mencatatkan angka popularitas $1.4 \%$ dan Andre Hehanusa 0.4\% (Lapora, 2019a). Ini disebabkan oleh intensitas kampanye yang rendah atau keduanya baru saja memulai aktivitas kampanye pada tiga bulan sebelum hari pemilihan. Hal ini terkonfirmasi dari pengakuan Valentinus Barobeda Casay, bahwa intensitas kampanye "Manohara baru dimulai pada 3 bulan sebelum hari pencoblosan dengan melakukan kampanye blusukan setiap minggu di seluruh titik pasar di Surabaya dan Sidoardjo" (wawancara penulis, 1 Agustus 2019). Aktifitas yang instan tersebut membuat pemilih tidak memiliki pengetahuan yang cukup bahwa seorang selebrititis tertentu mencalonkan diri sebagai calon anggota DPR dari Dapil tertentu.

Tabel 3. Data Popularitas dan Akseptabilitas Calon Anggota DPR RI di Dapil Jatim V

\begin{tabular}{|c|c|c|c|c|c|c|}
\hline \multirow[t]{2}{*}{ No } & \multirow[t]{2}{*}{ Nama Calon Legislatif } & \multirow[t]{2}{*}{ Partai } & \multirow{2}{*}{$\begin{array}{l}\text { Popular- } \\
\text { itas }\end{array}$} & \multicolumn{3}{|c|}{ Akseptabilitas } \\
\hline & & & & Suka & $\begin{array}{l}\text { Tidak } \\
\text { Suka }\end{array}$ & $\begin{array}{l}\text { Tidak } \\
\text { Jawab }\end{array}$ \\
\hline 1 & Krisdayanti & PDI-P & $25.10 \%$ & $38.60 \%$ & $8.50 \%$ & $52.9 \%$ \\
\hline 2 & Dra. Hj. Lathifah Shohib & PKB & $21.80 \%$ & $23.60 \%$ & $1.60 \%$ & $74.8 \%$ \\
\hline 3 & Dr. Ahmad Basarah & PDI-P & $11.80 \%$ & $15.10 \%$ & $1.60 \%$ & $83.3 \%$ \\
\hline 4 & Moreno Soeprapto, S.Sos & Gerindra & $11.70 \%$ & $15.10 \%$ & $4.40 \%$ & $80.5 \%$ \\
\hline 5 & Kresna Dewanata Prosakh & Nasdem & $8.90 \%$ & $9.30 \%$ & $1.20 \%$ & $89.5 \%$ \\
\hline
\end{tabular}

Kepopuleran Krisdayanti dan Ahmad Dhani didukung oleh fakta bahwa mereka adalah selebritis yang dilahirkan atau berasal dari daerah pemilihan dimana mereka terdaftar sebagai calon legislatif. Krisdayanti adalah seorang penyanyi papan atas yang lahir di Kota Batu. Sosok Krisdayanti, dan juga adiknya Yuni Sara, sebagai selebritis yang menjadi kebanggaan warga Malang Raya. Sementara Ahmad Dhani juga seorang selebritis yang lahir dan memulai karirnya di Surabaya. Tak heran jika keduanya memiliki popularitas yang tinggi di daerah pemilihan tersebut. Namun dari data tersebut pada tabel 1, kepopuleran Ahmad Dhani tidak didukung dengan tingkat penerimaan atau akseptabilitas dari masyarakat terhadap pencitraan dirinya. Sehingga dalam survey, tingkat ketidaksukaan masyarakat terhadap Ahmad Dhani juga cukup tinggi di angka 19\%. Ini disebabkan oleh arogansi dan rentetan skandal yang menimbulkan citra buruk bagi pemilih dari kalangan santri dan abangan.

Faktor lain yang menyebabkan rendahnya pengetahuan pemilih tentang keterlibatan calon selebritis adalah kecenderungan pemilih untuk tidak memproses informasi terkait politik dan pemilu secara serius. Mayoritas pemilih, sebagaimana dikemukakan oleh Lara Zwarun dan Angela Torrey, cenderung tidak mencari informasi 
yang banyak dan serius terkait keterlibatan calon selebritis dalam Pemilu (Zwarun \& Torrey, 2011). Sehingga para selebritis perlu membuat program pencitraan politik secara khusus untuk memberitahu publik bahwa mereka terjun ke dunia politik dengan membawa misi dan gagasan tertentu.

Tabel 4. Data popularitas dan Akseptabilitas Calon Legislatif RI

di Daerah Pemilihan Jatim VIII

\begin{tabular}{|c|c|c|c|c|c|c|}
\hline \multirow[t]{2}{*}{ No } & \multirow[t]{2}{*}{ Nama Calon Legislatif } & \multirow[t]{2}{*}{ Partai } & \multirow[t]{2}{*}{ Popularitas } & \multicolumn{3}{|c|}{ Akseptabilitas } \\
\hline & & & & Suka & $\begin{array}{l}\text { Tidak } \\
\text { Suka }\end{array}$ & $\begin{array}{l}\text { Tidak } \\
\text { Jawab }\end{array}$ \\
\hline 1 & Abd Muhaimin Iskandar & PKB & $29.1 \%$ & $34.9 \%$ & $5.3 \%$ & $59.8 \%$ \\
\hline 2 & H. Muhtarom, S.Sos & PKB & $7.2 \%$ & $10.5 \%$ & $0.4 \%$ & $89.1 \%$ \\
\hline 3 & Denada & PAN & $7.1 \%$ & $10.6 \%$ & $8.8 \%$ & $80.6 \%$ \\
\hline 4 & dr. Dewi Ema Anindia & Golkar & $5.6 \%$ & $15.6 \%$ & $6.8 \%$ & $77.6 \%$ \\
\hline 5 & $\begin{array}{l}\text { Mohammad Suryo Alam, } \\
\text { Ak, MBA }\end{array}$ & Golkar & $4.6 \%$ & $14.0 \%$ & $2.5 \%$ & $83.5 \%$ \\
\hline
\end{tabular}

Sumber: Survey Lapora Periode Februari 2019 (Lapora, 2019c)

Sementara data survey di Daerah pemilihan VIII menunjukkan ada gap popularitas yang cukup tinggi dalam persaingan antar calon legislatif. Sosok Muhaimin Iskandar sebagai ketua umum PKB memiliki popularitas tinggi karena dia merupakan tokoh politisi nasional yang memiliki akar yang kuat di Daerah pemilihan VIII. Faktor ketokohan seorang figur memang mendapat perhatian khusus dari pemilih. Figur Muhaimin Iskandar memiliki popularitas yang jauh melampaui kandidat-kandidat lainnya karena dia menyandang status sebagai tokoh dari daerah Jombang dan dan tokoh organisasi kemasyarakatan (Ormas) Nahdlatul Ulama.

Para politisi selebritis pada umumnya hanya memiliki popularitas namun minim rekam jejak ketokohan yang dibangun berdasarkan pencitraan dirinya di wilayah sosial dan wilayah politik. Masyarakat tampaknya enggan memberikan hak suara mereka kepada selebritis yang baru muncul pada saat-saat menjelang Pemilu. Hal ini dapat kita lihat dari respon masyarakat terhadap figur Denada, yang cukup dikenal oleh mereka yang mengikuti berita-berita seputar dunia hiburan tanah air. Selama masa kampanye Denada cukup aktif dalam pemberitaan di kolom gosip selebritis, khususnya terkait dengan penyakit kanker yang diderita oleh anak perempuannya. Masalah keluarga yang dihadapi Denada tersebut beberapa kali mendapat sorotan dari media massa nasional, dengan banyaknya kolega selebritis dan bahkan para politisi Nasional. Pada bulan Februari 2019 Denada berupaya memanfaatkan momen dimana putrinya dijenguk oleh Presiden Joko Widodo di Singapura. Pada konteks ini Denada berupaya membangun pencitraan melalui pendekatan parasosial. Pencitraan parasosial ini merujuk pada hubungan ilusif antara seorang individu dengan tokoh selebritis di media. Namun, 
HB Habibi S. \& Ahmad H. Ubaid | Selebritis Menjadi Politisi: Studi tentang Bagaimana Selebritis Menang...

pendekatan komunikasi parasosial itu tidak mampu mempengaruhi keterpilihan Denada di Daerah Pemilihan Jawa Timur VIII.

Relasi parasosial memang sangat mempengaruhi preferensi politik dari para pemilih (Centeno, 2016). Namun strategi kampanye Denada yang memanfaatkan strategi relasi parasosial yang mungkin tidak memiliki kesamaan dengan kebutuhan masyarakat. Pendekatan parasosial yang dilakukan oleh Denada dengan memanfaatkan penyakit kanker yang diderita oleh anak perempuannya serta meyakinkan masyarakat bahwa ia merupakan orang yang dianggap sebagai teman maupun kolega dari selebritis dan politisi nasional tidak mampu untuk menciptakan kesan bahwa ia merupakan teman dari masyarakat atau membuat masyarakat berempati dengan dirinya. Apa yang masyarakat butuhkan bukanlah sebuah bentuk kesamaan penderitaan namun solusi atas permasalahan yang ada pada mereka. Strategi parasosial memang sangat mempengaruhi pilihan politik karena membangun relasi pertemanan imajiner antara fans/massa dengan selebritis dan personalitas publik lainnya. Namun jika relasinya tidak dibangun dengan baik, maka kesannya seakan bahwa Denada merupakan sebuah "teman yang suka curhat" pada masyarakat, dalam bahasa kekinian.

Hal ini membuktikan bahwa relasi parasosial belum tentu cukup untuk mendapatkan modal sosial dan modal politik. Seorang selebriti membutuhkan modal sosial yang riil, dibangun melalui kegiatan sosial yang riil bersama dengan masyarakat. Atau setidaknya membangun relasi parasosial melalui pengurangan permasalahan yang ada pada masyarakat dan bukan dengan memberikan masalahnya pada masyarakat. Sekalipun selebritis merupakan seseorang yang populer dan mudah mendapatkan simpati, namun kondisi hidupnya tetap berada di atas kondisi masyarakat kelas menengah ke bawah sekalipun selebritis tersebut dalam kondisi yang krisis sesuai standar mereka. Sehingga pembangunan popularitas melalui relasi parasosial dan empatik tidak mungkin dapat dilakukan dengan memberikan permasalahan seorang selebritis terhadap masyarakat dan meminta masyarakat menyelesaikannya dengan memberinya jabatan dan pendapatan lain sebagai pejabat publik.

Seorang calon pejabat publik harus tetap menjadi orang yang dianggap memiliki solusi terhadap permasalahan masyarakat, maka modal popularitas dari selebritis adalah sebagai dukungan sekunder untuk mengkampanyekan solusi mereka terhadap permasalahan masyarakat. Modal sosial hanya bisa didapat melalui kedekatan dan kemampuan untuk menyelesaikan permasalahan masyarakat yang eksisten. Dalam hal ini, dapat disimpulkan bahwa popularitas tidak lebih dari supporting system dari usaha para politisi untuk mendapatkan modal sosial melalui kampanye program agar diterima oleh masyarakat. 


\section{Kasus I: Tumbangnya Para Caleg Selebritis di Dapil Jawa Timur I}

Dapil Jawa Timur I merupakan dapil yang cukup menyita perhatian banyak tokoh politik, dan tentu saja, para selebritis untuk maju sebagai anggota legislatif dalam Pemilu legislatif 2019 lalu. Tidak heran jika Dapil Jatim I banyak diisi oleh tokoh-tokoh yang mumpuni dalam bidangnya masing-masing. Dari sisi caleg yang berlatar belakang selebritis pun demikian. Banyak selebritis besar yang kemudian memutuskan untuk maju di dapil Jatim I yang juga banyak disebut sebagai dapil neraka. Sebagaimana diungkapkan sebelumnya, para caleg selebritis yang berkontestasi di Dapil Jatim I ini bukanlah caleg Petahana. Kontestasi antar calon legislatif DPR RI di Dapil Jawa Timur I memperebutkan sebanyak 10 kursi. Dapil ini merupakan wilayah perkotaan yang merupakan ibukota Jawa Timur, yang terdiri dari Kota Surabaya dan Kabupaten Sidoardjo.

Berdasarkan data survey Lapora, pilihan politik masyarakat berdasarkan Partai Politik pada Tahun 2019 yang tertinggi adalah PDI-P (18,0\%), kemudian diikuti PKB $(13,4 \%)$, Gerindra $(5,0 \%)$ dan Partai Demokrat $(4,5 \%)$. Selanjutnya ada $(4,5 \%)$ responden mengaku Golput dan (23,8\%) tidak tahu dan tidak menjawab (lihat Gambar 2). Data tentang survey tersebut memiliki kesesuaian dengan hasil pemilu legislatif 2019 dimana PDIP memperoleh 3 kursi, PKB memperoleh 2 kursi, dan kemudian partai-partai lain seperti Gerindra, Demokrat, Golkar, PAN, dan PKS masing-masing memperoleh 1 kursi.

Gambar 2. Diagram pilihan politik pemilih berdasarkan Partai di Dapil 1

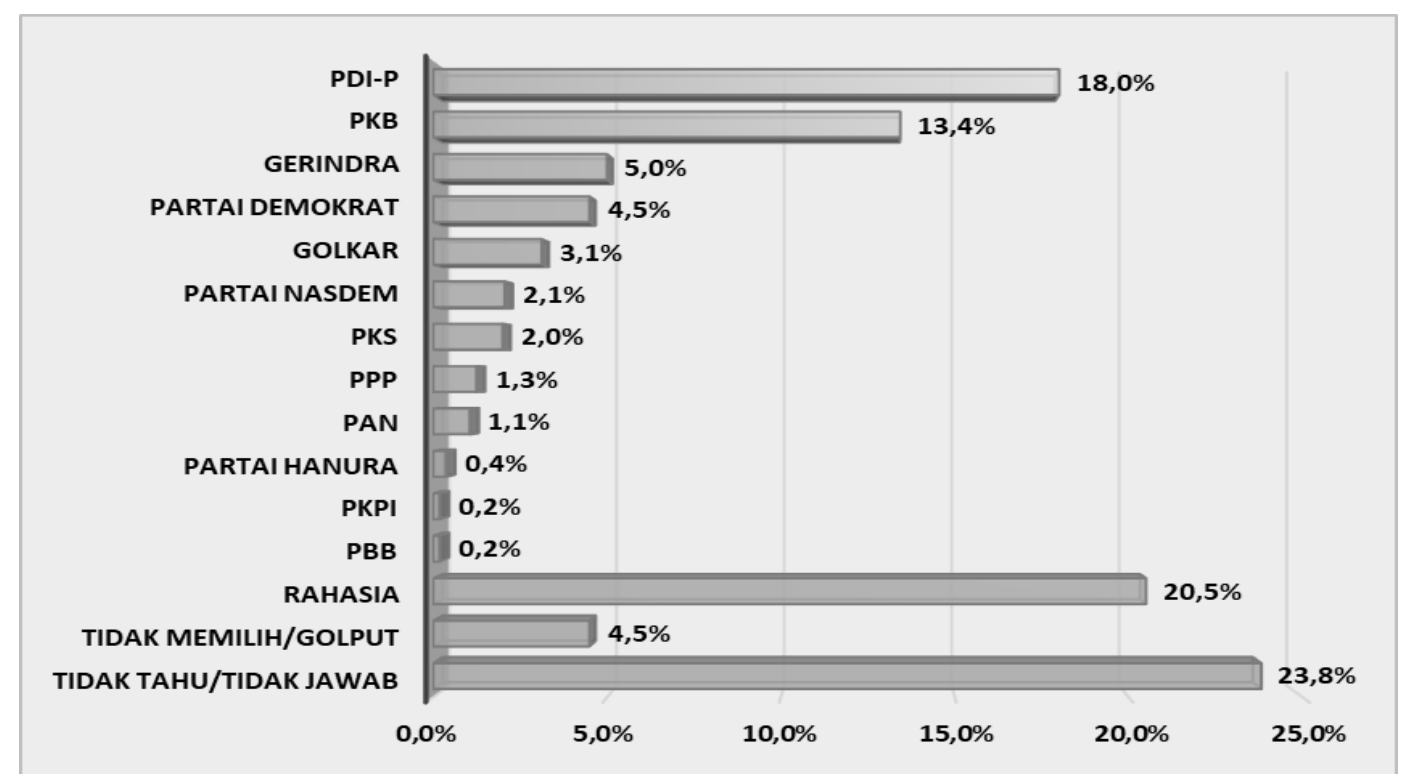

Sumber: Hasil Survey Lapora di Dapil Jawa Timur I (Lapora, 2019a)

Hal ini menunjukkan bahwa memang popularitas personal tidak mampu untuk mengangkat seseorang menjadi pilihan dari masyarakat. Popularitas partai dan kinerja mesin partai jauh lebih kredibel dibandingkan dengan popularitas seorang calon politisi 
HB Habibi S. \& Ahmad H. Ubaid | Selebritis Menjadi Politisi: Studi tentang Bagaimana Selebritis Menang...

selebritis dikarenakan pilihan masyarakat akan cenderung memilih calon legislatif yang berasal dari partai tersebut sekaligus bentuk dari kesuksesan mesin politik partai untuk mendapatkan suara di masyarakat. Dengan kata lain telah terjadi pergeseran politik dimana masyarakat tidak hanya melihat dari segala yang ada pada seorang calon legislatif, namun juga pada mesin politiknya yang memiliki reputasi baik skala Dapil maupun skala nasional.

Selain itu, modal awal dari selebriti adalah menggunakan populeritas sekaligus relasi parasosial. Namun sesuai dengan bahasan di bagian sebelumnya, relasi parasosial seorang selebriti dengan relasi parasosial seorang politisi akan jauh berbeda dikarenakan relasi parasosial seorang selebriti adalah dengan memanfaatkan empati publik pada personalitas dirinya. Sedangkan relasi parasosial seorang politisi dan tokoh publik adalah dengan memunculkan sebuah ide yang dapat menyelesaikan problematika masyarakat (Centeno, 2016).

Kasus ujaran kebencian yang menimpa Ahmad Dhani berdampak buruk pada pencitraan publik yang dia bangun untuk menarik simpati pemilih di Dapil 1. Keputusannya untuk mencalonkan diri di Dapil Jawa Timur 1 tidak koheren dengan strategi positioningnya untuk menarik simpati publik dari pemilih yang mayoritas mendukung partai pemerintahan, seperti PDIP dan PKB. Sekalipun keterlibatan Dhani dalam kasus ujaran kebencian merupakan sebuah ketaatan pada ideologi atau preferensi politik yang dianutnya, namun kontestasi di wilayah yang tidak simpatik dengan preferensi politiknya merupakan sebuah bunuh diri politik ketika tidak dimitigasi dengan intervensi personalnya. Kasus ini menarik dimana seseorang selebriti politik yang seharusnya ideal menurut Wheeler, dikarenakan Dhani seorang selebriti politik yang memiliki ketaatan dan pengertian terhadap sebuah preferensi politik dan ideologi, justru mengalami kekalahan dikarenakan kesalahan positioning dan ketidakmampuan untuk memitigasi dampak kesalahan tersebut (Wheeler, 2013).

Perbandingan yang dapat diberikan adalah pada figur Arzeti Bilbina, dimana Arzetti melakukan rajin melakukan kampanye yang bersifat simpatik terhadap masyarakat seperti melalui forum-forum pengajian ibu-ibu Muslimat NU, forum pengajian pesantren, dan kampanye massa PKB lainnya yang menyasar kalangan santri. Sosok Arzetti yang juga kontroversial karena gosip seputar permasalahan pribadinya lebih mudah diterima oleh masyarakat. Hal ini karena dia tidak mengusung preferensi ideologi tertentu yang bertentangan dengan pemilih mayoritas di Dapil 1. Hal-hal yang bersifat simpatik, seperti membangun ketokohan di jajaran pengurus NU, membuatnya mendapatkan populeritas yang besar di masyarakat (lihat Tabel 2). PKB sebagai partai politik yang mengusungnya juga memiliki popularitas sebesar $13,4 \%$. Tentu faktor-faktor ini dapat menjadi pertimbangan sebagai komunikasi parasosial yang bersifat empatik terhadap masyarakat. Arzetti Bilbina sebagai selebritis tidak menggunakan dirinya 
sebagai episentrum empati namun sebaliknya dia menunjukkan perannya melalui ormas dan mesin partai.

Keberhasilan Arzeti Bilbina lolos menjadi anggota DPR RI pun tidak sepenuhnya diperoleh karena popularitasnya sebagai seorang selebritis dan pola komunikasi parasosial yang dibangunnya. Pada saat kampanye dan mobilisasi suara dalam Pemilu, Arzeti memiliki keunggulan dari sisi mesin partai yang mendukungnya untuk memperoleh suara lebih besar. Menurut Achmad Faidy Suja'ie, salah seorang tim pemenangan DPP PKB Jawa Timur, dinyatakan bahwa:

"Keberhasilan Arzetti lolos sebagai anggota DPR RI adalah karena dia berkampanye di berbagai wilayah secara berpasangan dengan calon nomor urut 1, yaitu Syaikhul Islam. Mesin partai sebagian besar memperoleh pendanaan kampanye dan mobilisasi suara di Dapil 1 dibiayai oleh caleg nomor 1 tersebut. Sehingga dengan keunggulan konsolidasi tim pemenangan internal itu Arzeti mampu lolos menjadi anggota DPR dengan suara terbanyak kedua berdasarkan penghitungan akhir surat suara." (wawancara penulis, 8 Junli 2019)

Perbandingan lain dapat kita lihat dari Manohara sebagai caleg selebritis dari Partai Nasdem yang hanya memperoleh 6865 suara pada Pemilu. Sama halnya dengan Ahmad Dhani, kekalahan Manohara juga menjadi bukti bahwa status sebagai seorang selebritis tidak terlalu memberikan keuntungan signifikan dalam pencalonan sebagai anggota legislatif. Hal ini diakui oleh salah satu informan dari internal partai Nasdem Jatim, yaitu Valentinus Barobeda Casay, yang menyatakan bahwa:

“...Pada kampanye Pemilu Legislatif 2019 lalu, Manohara memulai kampanye pada 3 bulan sebelum hari H pemilihan. Dia melakukan kampanye blusukan hampir setiap minggu di setiap pasar di daerah Surabaya dan Sidoardjo. Namun kelemahannya adalah dia tidak melakukan politik uang pada hari Pemilihan"(wawancara penulis, 1 Agustus 2019)

Sementara itu, Andre Hehanusa gagal melaju menjadi anggota DPR RI karena modal popularitas dan ketokohannya tidak dapat mengalahkan nama besar caleg petahana lain seperti Puti Guntur Soekarno Putri dan Indah Kurniawati, serta Bambang DH yang merupakan mantan walikota Surabaya. Namun kepopulerannya sebagai selebritis setidaknya mampu membawa kontribusi sebesar 26139 suara dalam Pemilu legislatif 2019 lalu. Dengan perolehan suara tersebut, keberadaan Andre Hehanusa sebagai data-data tentang tersebut tentunya mengarahkan kita pada sebuah pandangan bahwa modal ketenaran selebritis tidak dapat mengantarkan seorang caleg untuk melaju menjadi anggota DPR RI tanpa strategi positioning, pencitraan yang tepat, dan dukungan dari mesin partai sebagai supporting system. 
HB Habibi S. \& Ahmad H. Ubaid | Selebritis Menjadi Politisi: Studi tentang Bagaimana Selebritis Menang...

\section{Kasus II: Kesuksesan Krisdayanti Di Dapil Jawa Timur V}

Daerah Pemilihan Jawa Timur V secara administratif meliputi wilayah pemilihan di 3 kabupaten yaitu Kabupaten Malang, Kota Malang, dan Kota Batu. Sebanyak 8 kursi DPR RI diperebutkan oleh 115 orang calon legislatif, yang terdiri dari 67 calon legislatif laki-laki dan 48 calon legislatif perempuan. Pada daerah Pemilihan V Jawa Timur ini, penulis memfokuskan pembahasan pada kandidat selebritis yaitu Krisdayanti yang dicalonkan dari Partai Demokrasi Indonesia Perjuangan (PDIP) dengan nomor urut 2. Secara historis Dapil Jawa Timur $\mathrm{V}$ ini merupakan basis pemilih dari kalangan santri (nahdliyin) dan abangan (nasionalis), atau wilayah yang secara mayoritas merupakan pemilih dari Partai Demokrasi Indonesia (PDIP). Hasil pemilihan umum sebelumnya pada tahun 2014 menunjukkan bahwa PDIP berhasil memperoleh 2 kursi, sementara PKB, Gerindra, Partai Nasional Demokrat, Partai Golkar, Partai Amanat Nasional, dan Partai Demokrat masing-masing berbagi 1 kursi.

Pada Pemilihan Umum tahun 2019, dengan menggunakan metode Sainte Lague, terdapat perubahan perolehan kursi. Menurut hemat penulis, pilihan politik masyarakat pada Pemilihan Umum 2019 menunjukkan adanya relevansi pada hasil survey Lapora berdasarkan pilihan pemilih terhadap Partai (lihat Gambar 3). Pemilih secara keseluruhan telah menentukan pilihannya berdasarkan partai dimana PDIP unggul jauh dengan 33\% suara. Berikutnya menyusul 4 partai lain yaitu PKB (15\%), Partai Nasdem (7,3\%), Partai Gerindra (6,6\%), dan Partai Golkar (5,6\%). Data survey tersebut menunjukkan bahwa PDIP akan dapat memenangi 3 kursi di DPR RI berdasarkan simulasi penghitungan suara sainte lague. Hasil penghitungan suara akhir pun menunjukkan bahwa PDIP secara total memperoleh 560.217 suara berdasarkan rekapitulasi penghitungan akhir KPU dan 3 anggota DPR RI dari partai itu lolos ke Senayan. Lonjakan perolehan suara drastis diperoleh oleh PDIP dan PKB, dimana kedua partai tersebut mendapat tambahan masing-masing satu kursi Anggota DPR.

Salah satu faktor yang mengangkat performa PDIP dalam pemilu legislatif adalah performa figur-figur yang terdaftar dalam surat suara. Secara popularitas figur, PDIP diuntungkan dengan kehadiran figur selebritis Krisdayanti pada daftar calon tetap partai. Krisdayanti merupakan diva musik yang sangat populer bagi warga Malang Raya karena dia dilahirkan di Kota Batu. Kiprahnya di dunia industri hiburan selalu menjadi bahan obrolan warga Malang sejak tahun 1990an hingga sekarang. Kedekatan hubungannya dengan warga Malang masih terbangun secara simbolik melalui bisnis makanan yang dijalankan oleh Krisdayanti di kota Malang. Kedekatan Krisdayanti dengan pemilih menempatkannya pada posisi pertama sebagai figur paling dikenal oleh masyarakat se-Malang Raya (lihat Tabel 3). 
Gambar 3. Diagram Pilihan Politik Pemilih Berdasarkan Partai di Dapil V

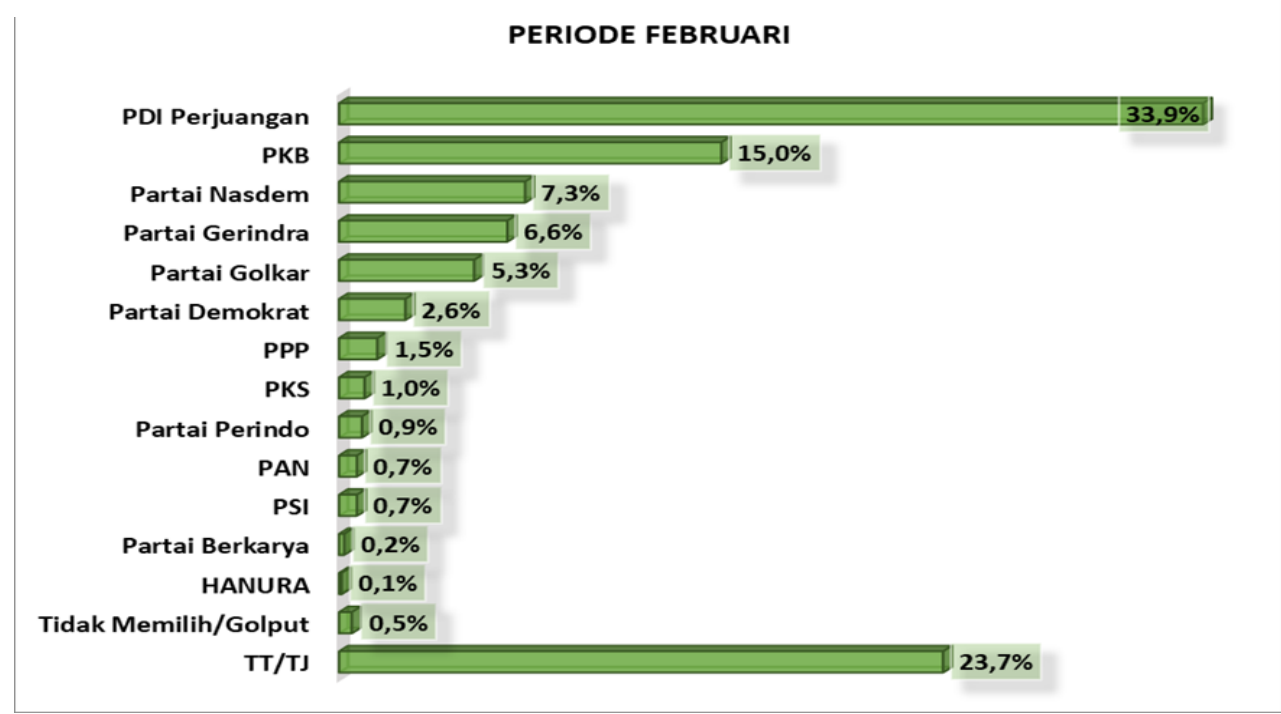

Sumber: Hasil Survey Lapora di Dapil Jawa Timur V (Lapora, 2019b)

Berdasarkan informasi dari Julius Eduardo Foeh, tim sukses Krisdayanti, kehadiran sosok selebritis dalam daftar calon legislatif dari PDIP mendapat sambutan yang meriah dari masyarakat. Lebih lanjut menurut Julius dijelaskan bahwa:

“...Menurut saya Krisdayanti terpilih karena murni kepopulerannya sebagai artis dan dia dapat menunjukkan citranya sebagai artis yang tidak elitis. Sama sekali kita tidak mengeluarkan biaya khusus untuk money politik. Biaya yang dikeluarkan lebih banyak untuk kampanye dan koordinasi di lapangan, serta pembuatan pemberitaan media massa dan branding di media sosial. Satu hal lagi, Krisdayanti mulai aktif turun ke masyarakat Malang Raya sejak bulan Oktober 2019 dengan mendatangi satu per satu rumah warga yang sudah ditentukan oleh tim pemenangan. Selama kampanye berlangsung setiap harinya mendatangi 4-5 rumah dengan durasi per rumahnya kurang lebih 15 menit. Setiap kali kampanye di rumah warga, akan muncul tawaran untuk mengunjungi desa atau rumah lain. Masyarakat akan berbondong-bondong mendatangi kampanye Krisdayanti dan ramai-ramai meminta foto selfie. Krisdayanti selalu dengan sabar melayani setiap permintaan foto selfie atau foto bareng warga tersebut. Di samping itu, kemampuan Krisdayanti berbahasa Jawa menjadi keunggulan sendiri baginya untuk berkomunikasi dengan warga." (wawancara penulis, 5 Juni 2019)

Krisdayanti merupakan figur yang memanfaatkan citra dirinya sebagai selebritis papan atas dan tidak segan menyapa masyarakat bawah dengan ramah. Secara garis besar, kampanye Krisdayanti di Dapil Jatim $V$ terbagi menjadi dua hal yaitu pencitraan melalui media massa dan kampanye blusukan dengan menyasar masyarakat secara langsung dari rumah ke rumah. Metode kampanye blusukan ini adalah metode yang 
HB Habibi S. \& Ahmad H. Ubaid | Selebritis Menjadi Politisi: Studi tentang Bagaimana Selebritis Menang...

awalnya dipopulerkan oleh Presiden Joko Widodo pada Pilkada Jakarta, dan Krisdayanti juga mengaplikasikan hal itu sebagai pencitraan bahwa dirinya didukung oleh partai pendukung Pemerintah.

Kampanye Krisdayanti juga didukung oleh para pemangku kepentingan setempat, baik Pemerintah Daerah dan Pemerintah Desa. Walikota Batu, Dewanti Rumpoko menjadi seorang endorser dari Krisdayanti. Menariknya dalam kasus ini, relasinya berubah dimana seorang pejabat publik menjadi endorser dari seorang selebriti dimana kondisi pada umumnya adalah sebaliknya. Tentu hal ini memunculkan sebuah dikotomi aktor politik, yakni selebriti politik (political celebrity) dan politik selebriti (celebrity politics). Krisdayanti merupakan sebuah contoh dari politik selebriti dimana partainya sekaligus pemangku kepentingan setempat memanfaatkan personalitas Krisdayanti sebagai selebriti untuk dimanfaatkan populeritasnya. Kebalikannya, Dewanti Rumpoko menjadi seorang selebriti politik yang berfungsi sebagai endorser dari Krisdayanti dikarenakan Dewanti Rumpoko merupakan seseorang yang telah sukses mendapatkan jabatan publik.

Dikotomi ini tentu bersifat fluid dan dapat berubah-ubah seiring dengan posisi dan kebutuhan dari masing-masing aktor, namun dalam tema selebriti seseorang dapat menjadi selebriti politik atau menjadi politik selebriti ketika ia memiliki status yang berbeda. Namun syarat menjadi politik selebriti adalah menjadi selebriti di luar politik terlebih dahulu sehingga dapat dimanfaatkan popularitasnya sebagai selebriti dan figur publik. Menurut Cardo (2013), berdasarkan pengalaman di Inggris telah terjadi sebuah peristiwa dimana seorang politisi diselebritikan sehingga menjadi hibrida antara selebriti politik dan politik selebriti melalui adanya serial "Tower Block of Commons". Serial ini merupakan sebuah reality show dimana 4 anggota parlemen Inggris hidup di berbagai wilayah yang kekurangan di seluruh Britania. Menurut Cardo, acara ini tidak sama sekali berusaha untuk menunjukkan bahwa politisi-politisi tersebut akan mengubah hajat hidup masyarakat di sana, namun hanya menunjukkan bahwa politisi-politisi tersebut hidup bersama dan berkoneksi dengan masyarakat di sekitar mereka (Cardo, 2014). Hal ini tidak menunjukkan bahwa politisi tersebut memiliki ide terkhusus dan mengimplementasikannya pada masyarakat tersebut, namun menunjukkan bahwa mereka membutuhkan koneksi dengan sekitarnya untuk membangun kepercayaan masyarakat. Tetapi, yang penting adalah dimana acara ini merupakan sebuah usaha untuk hibridasi antara selebriti politik dan politik selebriti dimana politisi aktif dijadikan sebuah selebriti melalui reality show. 


\section{Kasus III: Kegagalan Denada di Dapil Jawa Timur VIII}

Daerah Pemilihan Jawa Timur VIII merupakan wilayah konstituensi besar yang terdiri dari Kabupaten Mojokerto, Kabupaten Jombang, Kabupaten Nganjuk, Kabupaten Madiun, Kota Mojokerto, dan Kota Madiun. Sebanyak 10 kursi anggota DPR RI diperebutkan di Dapil Jatim VII ini. Wilayah ini merupakan basis dari pemilih dari kalangan santri dan abangan. PKB dan PDIP merupakan dua partai yang memiliki basis massa sangat baik dari wilayah pemilihan ini. Pada daerah konstituensi Jawa Timur VIII, hanya Partai Amanat Nasional yang mencalonkan selebritis yakni Denada, seorang penyanyi yang cukup kontroversial pada era tahun 1990-an, dan baru-baru ini kembali menjadi pemberitaan pada saat menjelang pemilu karena anaknya yang menderita kanker. Denada memiliki popularitas yang cukup tinggi yakni 7,1\%, dan tingkat akseptabilitas atau kesukaan masyarakat pada figurnya adalah 10,6\% dan sementara tidak disukai oleh 8,8\% (lihat Tabel 4).

Namun Denada tidak sukses mendapatkan kursi dalam dapil VIII dikarenakan ia tidak menggunakan komunikasi parasosial yang episentrumnya adalah masyarakat. la menggunakan kampanye bahwa ia akan menjadi orang yang bermanfaat dan menolong orang lain ketika mendapatkan penderitaan anaknya kanker dan berharap bahwa dengan menolong orang lain penderitaannya akan dikurangi oleh Tuhan. Kampanye tersebut diunggah melalui akun Youtube Channel bernama Aciek Lovers pada bulan Februari 2019. Tentu kampanye ini merupakan hal yang belum tentu mendapatkan simpati masyarakat dikarenakan episentrum parasosialnya adalah dirinya sendiri dan berusaha untuk melakukan pertukaran sesama untung dimana ketika ia menolong dan menyelesaikan permasalahan masyarakat maka Tuhan akan memberikan kesembuhan bagi anaknya. Terlihat dalam video tersebut, bahwa Denada menangis dan meminta masyarakat dengan mengandaikan bahwa jika ia dengan ikhlas membantu masyarakat maka harapannya masyarakat ikut mendoakan anaknya yang sakit serta Tuhan memberikan kesembuhan pada anaknya. Hal ini dapat membuat sebagian masyarakat tidak simpatik karena melihat bahwa Denada tidak ikhlas membantu masyarakat, namun hanya ingin mendapatkan doa dan simpati masyarakat agar anaknya cepat diberikan kesembuhan dari Tuhan.

Apa yang Denada maupun tim kampanyenya lupakan adalah mengenai permasalahan dan standar kehidupan yang dimiliki oleh masyarakat. Standar kehidupan ini tentu jauh lebih rendah dibandingkan dengan kondisi krisis atau permasalahan keluarga yang dialami oleh Denada. Sekalipun anaknya menderita kanker, namun masih bisa mendapatkan simpati dari politisi dan selebriti lainnya serta mendapatkan pengobatan kanker yang memadai dikarenakan kemampuan ekonominya yang masih di atas rata-rata masyarakat di dapil tersebut. Sehingga komunikasi parasosial empatik 
HB Habibi S. \& Ahmad H. Ubaid | Selebritis Menjadi Politisi: Studi tentang Bagaimana Selebritis Menang...

yang masih mendasarkan diri selebriti sebagai tempat empati masyarakat tentu tidak akan pernah berhasil jika kemampuan ekonomi dan standar hidupnya masih di atas ratarata masyarakat.

Faktor selanjutnya adalah dimana partai yang mengusung Denada bukanlah partai yang memiliki simpati signifikan di Dapil tersebut. PAN hanya memiliki populeritas $2,3 \%$, sangat rendah dibandingkan partai-partai lain dalam Dapil VIII (lihat Gambar 4). Berdasarkan hasil penghitungan suara yang dirilis KPU, perolehan suara PAN juga terlihat lemah di Tentu, sesuai dengan pembahasan sebelumnya, Denada tidak dapat untuk memanfaatkan massa partai maupun simpatisan partai untuk mendongkrak suaranya.

Apalagi dengan melihat fakta bahwa preferensi masyarakat yang hanya melihat popularitas sebesar 7,1\% dan elektabilitas sebesar 1,1\% (Lapora, 2019c), maka tidak ada signifikansi dari program pencitraan politik Denada bagi masyarakat di Dapil Jatim VIII. Studi kasus ini membuktikan bahwa masyarakat yang tidak memiliki preferensi atas popularitas yang tinggi akan terpengaruh oleh bagaimana seorang selebriti bisa mendapatkan simpati publik. Hal ini juga ditambah dengan ketidakmampuan selebriti tersebut untuk memberikan apa yang masyarakat inginkan yakni kemampuan politisi dan visi misinya yang memberikan manfaat pada masyarakat. Serta adanya kampanye Denada yang justru memberikan ruang pada masyarakat untuk menganggap bahwa Denada berpartisipasi dalam perpolitikan untuk kepentingan pribadi dan keluarganya serta menganggap menyelesaikan masalah masyarakat adalah perhitungan untung rugi atas kesembuhan anaknya.

Berdasarkan observasi di lapangan, Denada memulai kampanye dengan berdialog langsung bersama masyarakat dimulai pada Januari 2019. Program kampanye itu bisa dibilang sangat telat dari awal masa kampanye yang ditetapkan oleh KPU sejak bulan September 2018. Hal ini dikarenakan Denada harus menemani sang anak yang menderita sakit kanker. Mayoritas kampanye Denada banyak dilakukan oleh timnya dibandingkan dengan Denada langsung. Selain itu dia mengandalkan kampanye melalui media sosial Youtube dan Instagram. Denada juga tidak terlalu banyak melakukan kampanye yang bersifat langsung menyampaikan gagasan dan visi misinya, namun lebih banyak memanfaatkan waktu kampanyenya untuk komunikasi parasosial dengan menggunakan episentrum permasalahan kesehatan yang diderita anaknya. Alhasil, Denada hanya mampu meraih 43.573 suara dan kalah dari caleg PAN no 2, Abdul Hakim Bafagih dengan 56.848 suara. 
Kekalahan Denada membuktikan bahwa popularitas seorang artis tidak akan cukup membuat masyarakat akan memilihnya. Namun kerjasama tim sukses dan penguasaan wilayah yang justru akan membuat seorang caleg akan terpilih menjadi anggota DPR RI. Dari sisi persaingan di internal partai, Denada terbukti tidak mampu mengalahkan kerja keras dari caleg lokal yang rutin melakukan pemetaan wilayah dan memberikan bekal pelatihan untuk relawan dan mesin partainya (Mashudi, 2019). Secara popularitas sosok Denada memang memiliki keunggulan dari Abdul Hakim Bafagih. Namun dalam pemilu legislatif kita tidak dapat menafikkan faktor-faktor lain yang sifatnya lokal seperti hubungan kekerabatan dan ketokohan yang dimiliki oleh seseorang berkat pengaruh keluarganya (Kresna, 2019). Dalam konteks ini Abdul Hakim Bafagih memiliki keunggulan yang bersumber dari ketokohan ayahnya yang merupakan ketua DPD PAN Kota Kediri dan posisi kakaknya yang saat ini menjabat sebagai Walilkota Kediri (Adisurya, 2019). Modal sosial tersebut membuat Abdul Hakim Bafagih mampu dengan mudah mengkonsolidasikan jaringan tokoh masyarakat dan mesin Partai PAN di Dapil VIII sehingga menguntungkan dirinya selama masa kampanye dan pada saat mobilisasi suara. Di sisi lain, faktor kedekatan wilayah Kediri dan Dapil Jawa Timur VIII menjadi keunggulan tersendiri bagi Abdul Hakim Bafagih dimana dia dapat secara rutin

Gambar 4. Diagram Pilihan Politik Pemilih di Dapil VIII Berdasarkan Partai

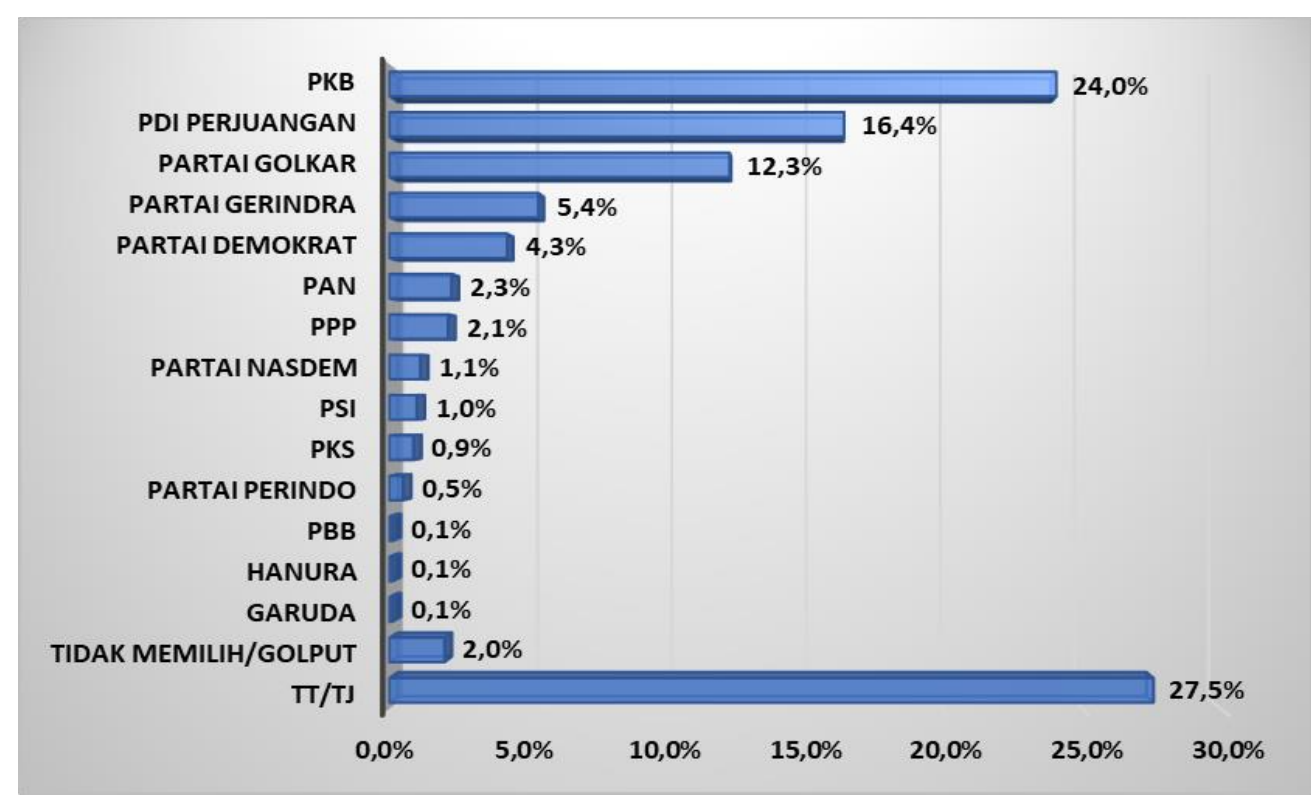

Sumber: Hasil Survey Lapora di Dapil Jawa Timur VIII (Lapora, 2019c)

melakukan kampanye kepada pemilih. Hal ini tentunya tidak dimiliki oleh Denada, yang lebih disibukkan dengan aktifitas seputar kesehatan anaknya selama masa sebelum kampanye.

Sekalipun perolehan Denada bisa dibilang signifikan dibandingkan calon-calon lain dikarenakan popularitasnya, namun minimnya intensitas kehadiran Denada secara 
HB Habibi S. \& Ahmad H. Ubaid | Selebritis Menjadi Politisi: Studi tentang Bagaimana Selebritis Menang...

langsung dan perubahan tema komunikasi parasosialnya maka tidak mungkin ia dapat mengeksploitasi popularitasnya secara signifikan dan menjadikan populeritasnya sebagai elektabilitas dengan mengkonversi populeritasnya sebagai supporting system dari gagasan yang akan ia berikan kepada masyarakat.

\section{Penutup}

Banyak faktor yang menentukan selebriti akan mendapatkan kemenangan dalam pencalonannya sebagai pejabat publik. Faktor pertama yakni Komunikasi parasosial empatik yang didasari oleh empati selebriti terhadap masyarakat. Selama ini pola komunikasi parasosial ala selebriti yang menempatkan dirinya sebagai episentrum perhatian akan mengalami kegagalan jika diaplikasikan dalam ranah politik. Berdasarkan data pada Pemilu legislatif lalu Denada adalah figur selebriti yang lebih banyak menggunakan episentrum dirinya dalam berkomunikasi politik. Sementara Krisdayanti dan Arzeti Bilbina menempatkan masyarakat sebagai episentrum komunikasi parasosialnya dengan aktif berkampanye blusukan dan menunjukkan ketokohan dalam Ormas tertentu. Sementara pada kasus Ahmad Dhani, dia justru melakukan pola komunikasi politik yang kontraproduktif terhadap status selebritis yang dimilikinya dan bertentangan dengan preferensi politik masyarakat.

Faktor kedua, pada even Pemilihan Umum legislatif, mesin partai dan popularitas partai sangatlah penting dimana mesin partai dan popularitas partai menjadi supporting system dari selebriti untuk dapat terpilih menjadi anggota legislatif. Mesin partai dan popularitas partai adalah alat untuk mengejawantahkan visi, misi dan gagasan dari politisi ketika selebriti tersebut tidak mampu menyampaikannya melalui personalitasnya. Jika tidak ada mesin partai yang kokoh, maka dibutuhkan seorang politisi aktif yang mampu untuk mengejawantahkan visi misi dan gagasan tersebut sebagai endorser dari selebritis, dimana relasi ini berkebalikan dengan politisi yang memanfaatkan selebritis sebagai endorser melalui populeritas. Hal ini dicontohkan melalui Krisdayanti yang memanfaatkan Dewanti Rumpoko (Walikota Batu) dan tokohtokoh politik lokal lain sebagai endorser dalam ranah visi, misi dan gagasan. Adanya figur Dewanti sebagai endorser menunjukkan bahwa Krisdayanti didukung oleh politisi sukses yang memiliki visi dan misi sejalan dengannya. Serta kesuksesan Krisdayanti tidak lepas dari popularitas PDI-P yang cukup relevan di Dapil Jatim $V$ dan mesin politiknya yang kuat.

Kontroversi seorang selebriti dalam berpolitik, maupun ketaatan seorang selebriti atas preferensi dan ideologi politik tertentu sangatlah penting ketika positioningnya tepat. Dengan positioning tepat dan kehadiran selebriti tersebut untuk menyampaikannya secara langsung maka selebriti tersebut dapat memiliki citra sebagai calon politisi yang handal dan teguh dalam prinsipnya. Adanya kesalahan positioning akan mengakibatkan seperti Ahmad Dhani yang justru semakin tidak populer 
dikarenakan kontroversinya dan mencalonkan diri di wilayah pemilihan yang simpati terhadap pihak yang diserang oleh ujaran kebenciannya di media sosial.

Fokus seorang selebriti yang tidak memiliki komunikasi parasosial yang baik adalah sebaiknya membangun komunikasi riil yang efektif dengan masyarakat yang akan diambil hatinya. Jika tidak mampu untuk membangun komunikasi parasosial berepisentrum masyarakat, maka selebriti ini harus mampu melakukan konsolidasi tim pemenangan yang berbasis relawan dan mesin politik partai.

\section{Ucapan Terima Kasih}

Kami mengucapkan terima kasih kepada Lapora yang berkenan memberikan data survey perilaku politik masyarakat di Dapil Jatim I, V, dan VIII. Ucapan terimakasih juga kami haturkan kepada para narasumber yang berkenan menjadi informan penelitian ini, dan pihak-pihak yang membantu dalam proses observasi lapangan.

\section{Pendanaan}

Penelitian untuk penulisan artikel ini dilakukan atas pembiayaan dari skema penelitian hibah internal dengan sumber dana DIPA Fakultas IImu Sosial dan IImu Politik, Universitas Brawijaya.

\section{Daftar Pustaka}

Adisurya, C. (2019). Kalahkan Denada, Abdul Hakim Bafagih, Pemuda Milenial Kota Kediri Dilantik Jadi Anggota DPR RI.

Aminuddin, M. F., \& Attamimi, N. H. (2019). From Retail to Grocery: Money Politics in 2014 Indonesian Legislative Election. Politik Indonesia: Indonesian Political Science Review, 4(1), 99-120.

Aspinall, E. (2014). Indonesia's 2014 elections: Parliament and patronage. Journal of Democracy, 25(4), 96-110.

Cardo, V. (2014). Celebrity politics and political representation: The case of George Galloway MP on Celebrity Big Brother. British Politics, 9(2), 146-160.

Centeno, D. D. G. (2016). Parasociality and habitus in celebrity consumption and political culture: A Philippine case study. Asian Journal of Social Science, 44(4-5), 441-484.

Darmawan, I. (2015). Keterlibatan selebriti dalam pemilu Indonesia pasca Orde Baru. Sosiohumaniora, 17(3), 230-236.

Downer, L. (2016). Political branding strategies: campaigning and governing in Australian politics.

Jati, W. R. (2014). Politik Selebritas Elaborasi Teoritik Terhadap Model Kampanye Baru. Jurnal Kawistara, 4(2).

Johnson, J. B., Reynolds, H. T., \& Mycoff, J. D. (2015). Political science research methods: Cq Press. 
HB Habibi S. \& Ahmad H. Ubaid | Selebritis Menjadi Politisi: Studi tentang Bagaimana Selebritis Menang...

KPU RI. (2019a). Data Pemilih Daerah Pemilihan Jawa Timur I. Retrieved from https://infopemilu.kpu.go.id/pileg2019/dapil/view. from Komisi Pemilihan Umum https://infopemilu.kpu.go.id/pileg2019/dapil/view

KPU RI. (2019b). Data Pemilih Daerah Pemilihan Jawa Timur V. Retrieved from https://infopemilu.kpu.go.id/pileg2019/dapil/view. from Komisi Pemilihan Umum https://infopemilu.kpu.go.id/pileg2019/dapil/view

KPU RI. (2019c). Data Pemilih Daerah Pemilihan Jawa Timur VIII. Retrieved from https://infopemilu.kpu.go.id/pileg2019/dapil/view. from Komisi Pemilihan Umum https://infopemilu.kpu.go.id/pileg2019/dapil/view

Kresna, M. (2019). Caleg Muda Bergelimang Privilese Keluarga. Retrieved from https://tirto.id/caleg-muda-bergelimang-privilese-keluarga-dlsa

Kumparan. (2018). Daftar 91 Caleg Artis DPR RI di Pileg 2019. Retrieved from https://kumparan.com/kumparannews/daftar-91-caleg-artis-dpr-ri-di-pileg2019-1q3BDfE9tCR

Lane, M. (2015). Indonesia's 2014 Legislative Elections: The Dilemmas of "Elektabilitas" Politics. In U. Fionna (Ed.), ISEAS Perspective: Watching the Indonesian Elections 2014 (pp. 75-84): ISEAS-Yusof Ishak Institute.

Lapora. (2019a). Survey Kondisi Sosial, Politik Dan Ekonomi Di Dapil I. Retrieved from Malang:

Lapora. (2019b). Survey Kondisi Sosial, Politik Dan Ekonomi Di Dapil V. Retrieved from Malang:

Lapora. (2019c). Survey Kondisi Sosial, Politik Dan Ekonomi Di Dapil VIII. Retrieved from Malang:

Lent, R., \& Tour, G. (2009). Selling Luxury: Connect with Affluent Customers, Create Unique Experiences Through Impeccable Service, and Close the Sale: John Wiley $\&$ Sons.

Mashudi, D. (2019). Abdul Hakim Bafagih Kaum Milenial Kota Kediri Calon Anggota DPR RI. Retrieved from https://jatim.tribunnews.com/2019/09/28/abdul-hakimbafagih-kaum-milenial-kota-kediri-calon-anggota-dpr-ri

Scammell, M. (2015). Politics and image: the conceptual value of branding. Journal of political marketing, 14(1-2), 7-18.

Ubaid, A. H., \& Subandi, H. H. (2018). Political polarization based on religious identities: Empirical evidence from the 2017 Jakarta gubernatorial. Jurnal Studi Pemerintahan, 8(4), 411-441.

West, D. M., \& Orman, J. M. (2003). Celebrity politics: Prentice Hall.

Wheeler, M. (2013). Celebrity politics: Polity.

Wood, N. T., \& Herbst, K. C. (2007). Political star power and political parties: Does celebrity endorsement win first-time votes? Journal of political marketing, 6(23), 141-158.

Zwarun, L., \& Torrey, A. (2011). Somebody versus nobody: An exploration of the role of celebrity status in an election. The Social Science Journal, 48(4), 672-680. 


\section{Daftar Narasumber}

Ahmad Faidy Suja'ie, Koordinator Tim Pemenangan PKB Dapil Jatim 1, 08 Juli 2019, pukul 09.00 WIB.

Hendro Tri Subiantoro, Wakil Ketua DPD Gerindra Jawa Timur, 22 Juli 2019, pukul 12.00 WIB.

Juluis Eduardo Luther Foeh, Tim Pemenangan Krisdayanti Pemilu 2019, 05 Juni 2019, Pukul 15.00 WIB.

Valentinus Barobeda Casay, sekretaris DPW Partai Nasdem Jawa Timur, 01 Agustus 2019, Pukul 16.00

\section{Tentang Penulis}

HB Habibi Subandi adalah dosen Program Studi IImu Politik, Fakultas IImu Sosial dan Ilmu Politik, Universitas Brawijaya. Penulis memiliki area riset seputar tema kebijakan publik, identity politics, indonesian politics.

Ahmad Hasan Ubaid adalah dosen Program Studi Ilmu Politik, Fakultas IImu Sosial dan Ilmu Politik, Universitas Brawijaya. Penulis memiliki area riset seputar tema demokrasi, politik kepemiluan, political marketing. 